\title{
Hepatocellular Carcinoma in Adults
}

\author{
Aducio L. Thiesen \\ Department of Laboratory Medicine and Pathology, University of Alberta, Edmonton, AB, \\ Canada
}

Author for correspondence: Aducio L. Thiesen, Department of Laboratry Medicine and Pathology, University of Alberta Hospital, Edmonton, Alberta, Canada.

Email: athiesen@ualberta.ca

Doi: https://doi.org/10.36255/exonpublications.livercancer.2021.ch2

\begin{abstract}
Hepatocellular carcinomas are the most common primary neoplasia of the liver. The global distribution of hepatocellular carcinoma is related to the prevalence of hepatitis $C$ in the population. Other major etiologic factors include alcoholic liver disease and nonalcoholic steatohepatitis. The majority of cases are discovered when screening patients with either chronic hepatitis or cirrhosis, but occasional incidental cases have been reported. Molecular markers and associated gene alterations are a work in progress. Serological markers and radiology are used to detect the disease in high-risk populations, and to monitor response to therapy in the affected patients. Even though radiologic features are specific, tissue diagnosis may be required, particularly for atypical and smaller lesions. Ancillary studies including reticulin stain and immunohistochemistry are important for confirmatory diagnosis. Liver transplantation is curative for hepatocellular carcinoma, but due to limitations in organ availability, palliative care is required, which mostly includes chemoembolization and radio-ablation.
\end{abstract}

Keywords: alpha fetoprotein; BCLC staging; CLIP staging; hepatocellular carcinoma; Okuda staging

In: Liver Cancer. Sergi CM. (Editor). Exon Publications, Brisbane, Australia. ISBN: 978-0-6450017-2-3; Doi: https://doi.org/10.36255/exonpublications.livercancer.2021

Copyright: The Authors.

License: This open access article is licenced under Creative Commons Attribution-NonCommercial 4.0 International (CC BY-NC 4.0) https://creativecommons.org/licenses/by-nc/4.0/ 


\section{INTRODUCTION}

Malignancies that arise from hepatocytes are denominated hepatocellular carcinomas. Hepatoma is another term; however, this old terminology implies a benign process and therefore, to avoid confusion, this term should not be used. Hepatocellular carcinomas are malignant tumors and have the capacity to metastasize and cause death. The most common sites of metastases are lungs, abdominal lymph nodes and bones (1). Since hepatocytes are the most abundant cells within the liver, hepatocellular carcinoma is the most common primary liver disease in adults ( $85 \%$ of the malignancies of the liver). It is the $6^{\text {th }}$ most common malignancy worldwide with 841,080 cases in 2018 and predicted to be $1,361,836$ in 2040 with significant mortality and morbidity (2). The incidence of hepatocellular carcinoma is directly related to geography and prevalence of infectious diseases. The highest rates of disease are found in Asia and southern Africa (up to 150 per 100,000), mostly due to the high prevalence of infectious hepatitis. In the USA, the prevalence is much less but still significant (6 per 100,000), typically affecting Asian men (3). The epidemiology is similar in Canada with a reported prevalence of 6.8 per 100,000; this significant rise $(3 \mathrm{x})$ since the 1980 s is likely related to the expansion of intravenous drug abuse and consequent increase in cases of hepatitis C (4). In Europe, the rate ranges from 3 to 6 per 100,000 individuals depending on the availability of treatment and prevention of infectious hepatitis, and abuse of alcohol (5). Hepatocellular carcinoma is the second leading cause of cancer mortality worldwide. Screening programs and curative therapy for infectious hepatitis have contributed to a decrease in mortality but alcohol abuse and metabolic diseases including diabetes and obesity have surpassed the initial benefit $(6,7)$.

\section{ETIOLOGY AND PATHOGENESIS}

The hepatocytes are active metabolic cells involved in many cell functions and are subject to a large number of insults that may result in abnormal proliferation (8). Exhaustion of their regenerative capacity is typically exemplified by cirrhosis. Thus, the etiologic factors involved in the cirrhotic process are also involved in tumorigenesis of hepatocellular carcinoma. Chronic hepatitis B and C are by far the most common causes of hepatocellular carcinoma, followed by alcoholic liver disease and nonalcoholic steatohepatitis. (9-11). Hepatitis B DNA levels in excess of 200,000 IU/mL (1,000,000 copies $/ \mathrm{mL})$ have been reported to increase the incidence of hepatocellular carcinoma to 1,152 per 100,000 individuals $(12,13)$. Other etiologic factors in adults include aflatoxin-contaminated food, diabetes, obesity, and hemochromatosis $(14,15)$. In some instances, hepatocellular carcinoma is detected incidentally during routine image examination. These tumors are considered sporadic and are result of gene mutations that occur during a person's lifetime.

Genetic susceptibility to hepatocellular carcinoma has been demonstrated in animal models, but not established in humans. Family clustering has been 
reported in some Chinese families and Alaskan natives, but infectious hepatitis B is a requirement for HCC development in this particular population $(16,17)$.

Other etiologic factors include conditions associated with congenital, genetic, and metabolic conditions and are directly related to the capacity of these pathologies to develop cirrhosis. Such examples include hemochromatosis, Wilson's disease, alpha-1-antitrypsin deficiency and Budd-Chiari syndrome.

Alcoholic liver disease is a risk factor that illustrates regeneration as the key factor in tumorigenesis. Active intake of alcohol causes hepatocyte injury with minimal regeneration, which clinically is a low risk factor for hepatocellular carcinoma. In contrast, alcohol abstinence results in significant regeneration and a higher risk of hepatocellular carcinoma (18).

Once the hepatitis B virus is integrated into the hepatocytes, transactivation of proto-oncogenes, activation of growth factors, and inactivation of tumor suppressor genes may result in abnormal proliferation (19). The hepatitis $C$ virus damages double-stranded DNA, increasing the frequency of mutations in genes such as immunoglobulin genes, BCL-6, TP53, and $\beta$-catenin, causing abnormal proliferation (20). Other common mutations encountered in hepatocellular carcinoma include: telomerase promoter mutations (30 to $60 \%$ of HCC) (21); TP53 mutations (18 to 50\%) (22) classically associated to exposure to aflatoxin; beta-catenin (18 to 40\%); AXIN1 and AXIN2 genes; chromatin remodeling pathway (ARID1A and ARID2); Janus kinase (JAK)/signal transducers and activators of transcription (STAT) pathway (JAK1, IL6R, and IL6ST); genes involved in ubiquitination (KEAP1); genes involved in RAS/MAPK signaling (RPS6KA3); and genes involved the oxidative stress pathway (NFE2L2) (23).

\section{NATURAL HISTORY AND PRE-NEOPLASTIC LESIONS}

At the cellular level, hepatocellular carcinomas are thought to arise from a dysplastic focus (less than $1 \mathrm{~mm}$ ) that develops into either a low-grade or a highgrade dysplastic nodule. The high-grade dysplastic nodule, more frequently than the low-grade dysplastic nodule, progresses to hepatocellular carcinoma (24). Since the primordial lesion (dysplastic focus) is less than $1 \mathrm{~mm}$, it is not identifiable by radiologic studies and usually observed in hepatectomy specimens as focal cytological atypia within the hepatocytes. Morphologically, the atypia within the hepatocytes is described as small and large cell changes. The small cell change is characterized by increased nuclear to cytoplasmic ratio, hyperchromasia and cytoplasmic basophilia, giving the impression of crowding. Small change atypia is associated with high-grade dysplastic nodules and a higher risk of developing of hepatocellular carcinoma. The large cell change is characterized by enlarged cells with larger nuclei and cytoplasm, but the nuclear to cytoplasmic ratio is preserved; frequent multinucleation, nuclear polymorphism and hyperchromasia are common. Large cell changes are the predominant alteration in low grade dysplastic nodules and indicate a benign feature (25). The biggest diagnostic challenge is to differentiate a high-grade dysplastic nodule from a well-differentiated hepatocellular carcinoma. Reticulin stain with delineation of the hepatic plates is a reliable ancillary technique in this context. Preservation of the hepatic plate is typical 
of a high-grade dysplastic nodule, whereas expansion of the hepatic plates is typical of hepatocellular carcinoma. Other morphologic criteria for hepatocellular carcinoma include increased cell nuclei with consequent increased nuclear to cytoplasmic ratio, pseudogland formation and unpaired arteries with absence of portal triads (Figure 1), and sinusoidal capillarization appreciated with CD34 immunohistochemistry and stromal invasion without ductular reaction at the periphery of the nodules (26). The size of the lesion may also be helpful, especially radiologically, with lesions larger than $1 \mathrm{~cm}$ and less than $3 \mathrm{~cm}$ usually classified as dysplastic nodules, and lesions more than $3 \mathrm{~cm}$ as hepatocellular carcinoma (27).

Other preneoplastic lesions include clonal proliferation of hepatocytes forming hepatocellular adenomas. These lesions are characterized morphologically by well circumscribed proliferation of bland hepatocytes with intact hepatic plates and absence of portal triads. The real differential in this situation includes mostly a well differentiated hepatocellular carcinoma. Ancillary studies such as immunohistochemistry for CD34 demonstrating complete capillarization of the sinusoids, immunohistochemistry for Glypican-3 and reticulin stain (Figure 2) are helpful for differential. Hepatocellular adenomas are occasionally linked to oral contraceptives (28). Other possible etiologies include the use of clomiphene (used as hormonal treatment for infertility issues) (29), methyltestosterone (anabolic steroid) (30)

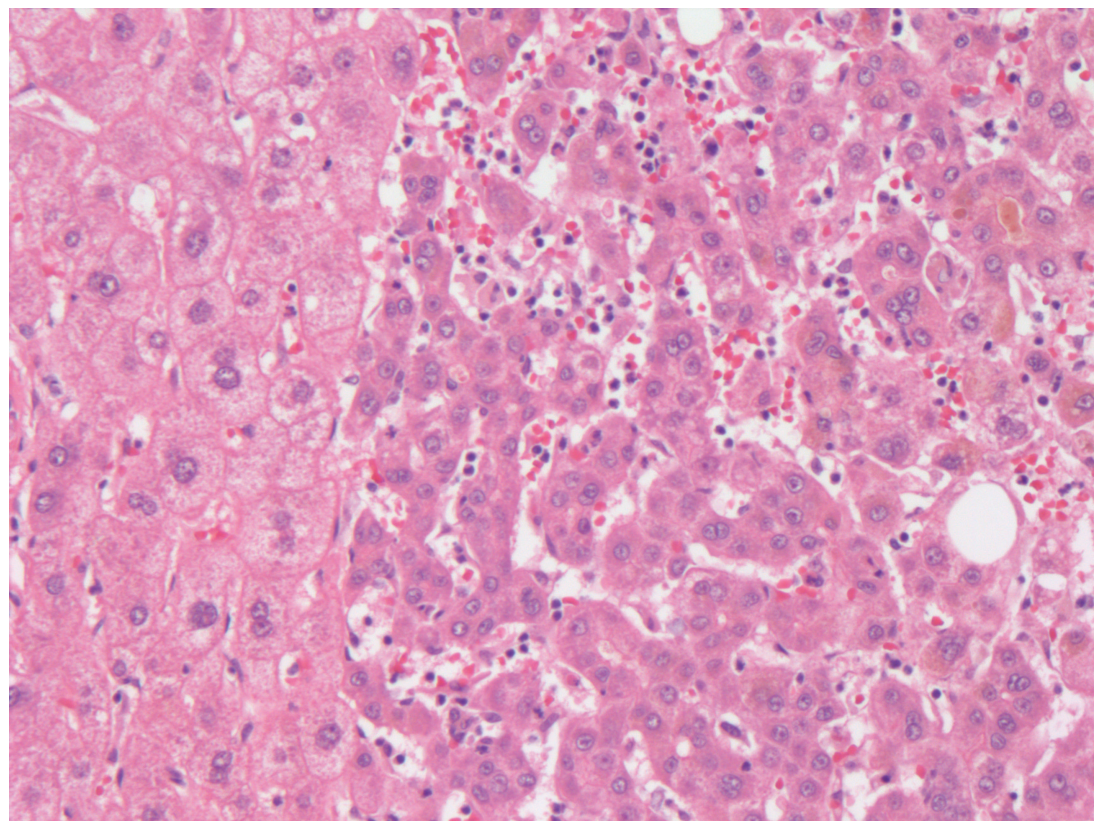

Figure 1. Hematoxylin and Eosin stain 200X. On the left, normal hepatocytes with normal nuclear cytoplasmic ratio as compared to hepatocellular carcinoma (on the right) with increased nuclear cytoplasmic ratio, organized into thick trabeculae and few pesudoglandular structures with bile. 


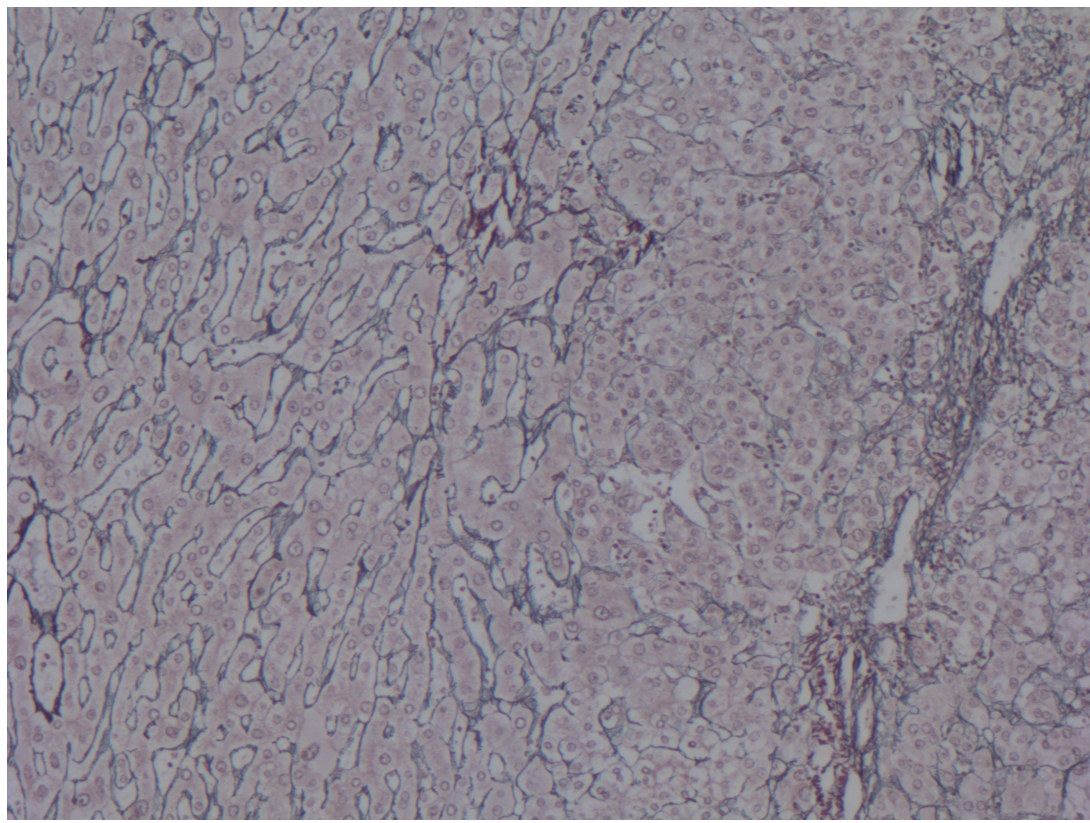

Figure 2. Reticulin stain 200x. On the left, normal hepatocytes with one to two cell thick hepatic plates as compared to hepatocellular carcinoma (on the right) with distended hepatic plates.

and danazol (synthetic androgen used for treatment of endometriosis) (31). At the molecular level, hepatocellular adenomas are subdivided based on HNFla mutations (steatotic adenomas), IL-6/STAT3 mutations (inflammatory adenomas), and $\beta$-catenin mutations (subgroup of inflammatory adenomas and unclassified adenomas with cytological atypia) (32). Prognostic implications justify such subtyping with inflammatory adenomas being frequently associated with metabolic syndrome, liver steatosis and alcohol exposure (33), and the $\beta$-catenin mutated adenomas immunophenotypically represented by nuclear staining associated with a higher risk of malignancy. Extensive literature and classification of hepatocellular adenomas is available, but the key is the identification of the lesions with great risk of progression to hepatocellular carcinoma.

\section{CLINICAL CHARACTERISTICS, DIAGNOSIS, AND DIAGNOSTIC TESTS}

Hepatocellular carcinoma usually affects the younger population. This is most likely related to significantly higher viral infection rate in individuals of reproductive age. Males are more affected than females, and males are also more frequently involved with alcohol abuse (34). Most patients are asymptomatic. 
However, symptoms related to predisposing risk factors (cirrhosis and viral infections) are frequent, such as ascites and esophageal varices. Paraneoplastic syndromes may be occasionally associated with hepatocellular carcinoma, such as hypoglycemia (35), erythrocytosis (36), hypercalcemia (37) diarrhea (38) and cutaneous lesions (39). Other less common presentations include fever, infections, obstructive jaundice, and hemorrhage due to tumor rupture. Lymph node involvement is not common, and 10 to $15 \%$ of the cases present with advanced disease and metastases to lung, bone, and adrenal gland (40, 41).

Serological markers of the disease include alpha fetoprotein (AFP), heat shock protein, human cervical cancer oncogene, human telomerase reverse transcriptase mRNA, certain cytokines and microRNAs. AFP is by far the most used due to its availability, but screening limitations are significant due to its low sensitivity (41 to $65 \%$ ). Pregnancy and primary liver and gastrointestinal disease also raise the levels of AFP, giving false positive results (42). The most accepted cut-off value is a serum concentration of $20 \mathrm{ng} / \mathrm{mL}$ (43). However, the most valuable indication of AFP is in the follow-up of previously treated hepatocellular carcinoma to detect the risk of recurrent disease (44). Three different glycoforms of AFP have been identified: AFP-L1, AFP-L2 and AFP-L3. The latter has been reported to be associated with more aggressive liver disease and consequently worse prognosis $(45,46)$. Glypican-3, a plasma membrane protein involved in the interaction with growth factors, has been suggested as an adjuvant serologic marker in addition to AFP to increase the sensitivity of detecting hepatocellular carcinoma $(47,48)$. Other liver enzymes have also been proposed in association with AFP to promote screening for hepatocellular carcinoma such as gamma-glutamyl transferase, Alpha-lfucosidase and Des-gamma-carboxyprothrombin. Alternatively, instead of protein levels, mRNA levels of AFP and GGT may also be helpful prognostic factor after initial therapy for $\operatorname{HCC}(49,50)$.

Additional serological markers in conjunction with AFP have been proposed to increase the sensitivity of detection such as alpha-L-fucosidase (AFU) and transforming growth factors alpha and beta (TGF- $\alpha$ and TGF- $\beta$ ) (51)

Radiologic diagnosis of hepatocellular carcinoma has significant implications for treatment options, with dysplastic nodules conservatively followed up based on the fact that one third of these lesions may progress to hepatocellular carcinoma; and early hepatocellular carcinoma should be treated with possible curative options such as ablation, resection and transplant (52). The image modality typically used is ultrasonography, likely due to the availability, but the sensitivity of $65 \%$ and specificity of $90 \%$ justify the use of more advanced image studies (53). In referral centers, the image protocol includes four-phase multidetector computed tomography (CT) or dynamic contrast enhanced magnetic resonance imaging (MRI), complementing each other, when suspicious features are noted (54). The distinction and detection of hepatocellular carcinoma is based on changes of vascularization including the presence of unpaired arteries and capillarization of the sinusoids that can be observed by image studies $(55,56)$. The definite radiologic criteria for the diagnosis of hepatocellular carcinoma are defined by contrast hyperenhancement at the arterial phase and hypoenhancement at the venous phase for lesions larger than $2 \mathrm{~cm}(57,58)$. This criterion is highly specific and has replaced biopsy since 2000 (59). For lesions less than $2 \mathrm{~cm}$, there is intense debate regarding the need of a biopsy, or not to define the lesion. Lesions less than $1 \mathrm{~cm}$ tend to be biopsied but there is variation in practice among centers (60). 
When atypical nondiagnostic inconclusive features are noted by radiology, a biopsy is indicated. Most are image-guided targeted biopsies of the lesions, but a biopsy away from the lesion may be useful to assess other conditions, for example cirrhosis, that may increase the risk of hepatocellular carcinoma. Biopsy is preferred over fine needle aspiration due to the low sensitivity (67\%) of the cytology specimen, although complications such as seeding is obviously higher in the more invasive biopsy procedure (61). The risk of seeding is small but considerable, being estimated at 2.7\% (62). The hallmark of a neoplastic proliferation within a biopsy is the lack of portal triads. Features of hepatocellular differentiation such as bile production and canaliculi are important when distinguishing a metastatic lesion (63). Reticulin stain as previously commented highlights thickening of the hepatic plates (more than 3 cell thick) and the cytologic features will define the histologic grade of hepatocellular carcinoma. The best differential between hepatocellular carcinoma and hepatic adenoma is immunohistochemical stains for glypican-3 or AFP. However, AFP stain in some laboratories has a lot of background, making it very difficult to interpret. Glypican-3 may also be focal within the lesion and the representative core biopsy may be completely negative. By morphologic analysis, hepatocellular carcinoma may be classified as well-, moderately, and poorly differentiated, based on resemblance to normal hepatocytes. Well-differentiated tumors have slightly enlarged nuclei and increased nuclear to cytoplasmic ratio and may be very difficult to differentiate from normal hepatocytes. Moderately differentiated tumors have slightly thicker hepatic plates and larger cells. Poorly differentiated tumors are heterogeneous and have characteristics of an immature tumor with no typical differentiation or maturation, requiring immunohistochemical markers to obtain adequate and conclusive diagnosis (64).

Immunohistochemical markers are widely used in hepatobiliary pathology. The most useful marker is HEP PAR-1, a marker of hepatocellular differentiation but not useful for distinction between benign and malignant hepatocytes. Glypican- 3 (Figure 3) and arginase-1 are specific markers for malignancy transformation (65). Supportive markers such as CD34 display typical capillarization of the sinusoids (Figure 4), and CD10 and pCEA demonstrate typical canalicular pattern. In addition, as an initial panel to exclude other possibilities, cytokeratins such as CK7 and CK20 are routinely used with the typical immunophenotype for HCC consisting of negativity for both markers.

Many histologic variants of hepatocellular carcinoma have been described and some have no clinical significance and may be confused with other entities. Such examples include clear cell hepatocellular carcinoma mimicking a metastatic clear cell renal cell carcinoma, pseudoglandular hepatocellular carcinoma mimicking a metastatic adenocarcinoma and scirrhous hepatocellular carcinoma mimicking a cholangiocarcinoma $(66,67)$. In other situations, recognition of a particular histologic variant is significant as in the case of diffuse cirrhosis-like hepatocellular carcinoma that radiologically mimics cirrhosis, and for that reason is usually missed (68). The same may be said of other variants such as giant cell variant and combined hepatocellular carcinoma and cholangiocarcinoma recognized as tumors with worse prognosis (66). Other variants are presumed to have better prognosis such as pedunculated hepatocellular carcinoma and fibrolamellar hepatocellular carcinoma (69). Finally, some variants are related to adjuvant therapy as ablated HCC causing significant necrosis (70). 


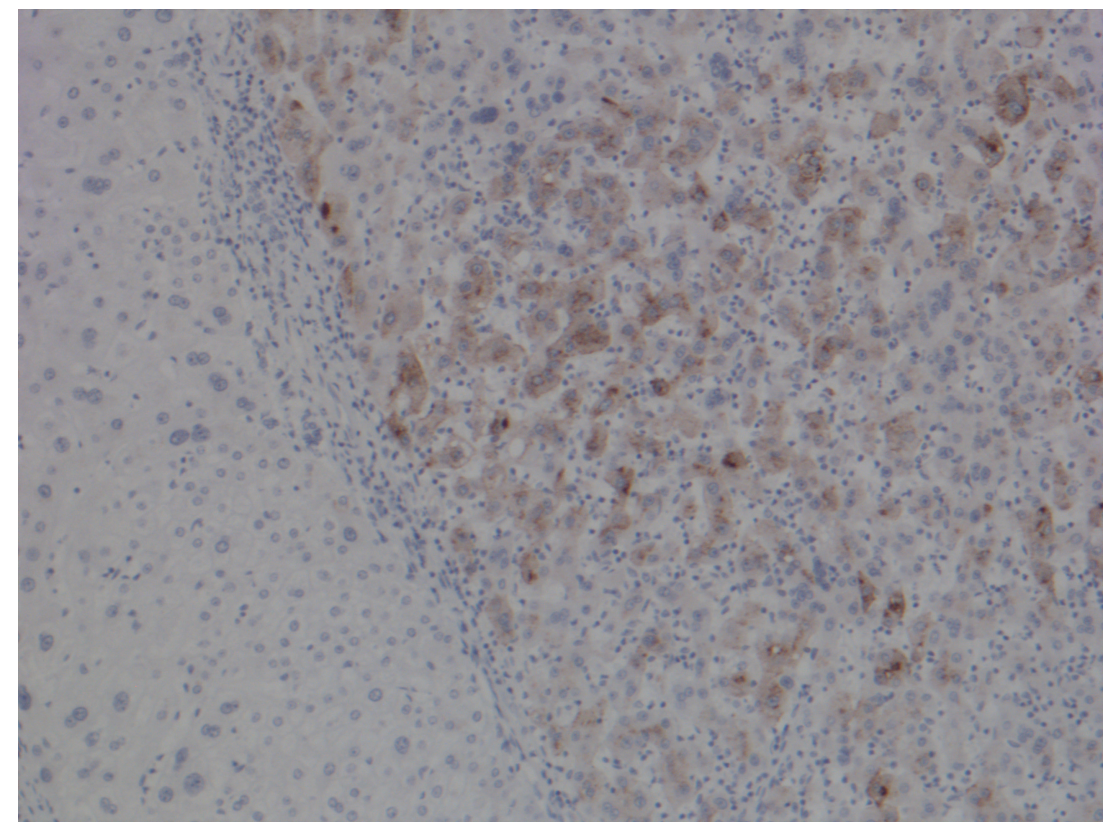

Figure 3. Immunohistochemistry for Glypican- 3 200X. On the left, normal hepatocytes with no staining (brown pigmentation) as compared to hepatocellular carcinoma (on the right) with cytoplasmic and few nuclei staining positive (brown discoloration).

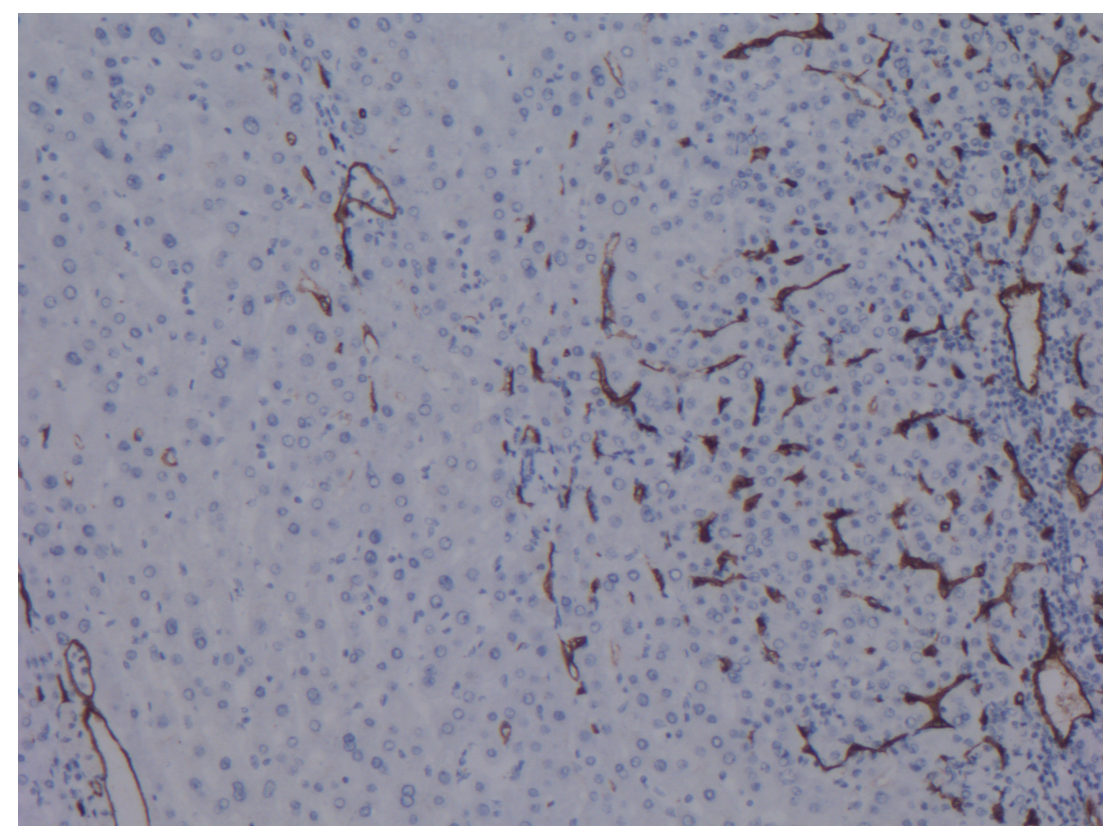

Figure 4. Immunohistochemistry for CD34 200X. On the left, normal hepatocytes with no staining (brown discoloration) of the sinusoids as compared to hepatocellular carcinoma (on the right) with positivity within the sinusoids indicating capillarization. 


\section{STAGING}

After diagnosis, staging of disease is required for adequate prognostication and subsequent therapy. The current staging systems include the pathologic tumornode-metastasis (pTNM) (Table 1), the Okuda and the Cancer of the Liver Italian Program (CLIP) (Table 2), and the Barcelona Clinic Liver Cancer (BCLC) (71) (Table 3). The pTNM staging system is purely morphology-based and the other systems are mixed, using both morphology and clinical parameters to predict prognosis. The pTNM system fails to consider the residual function of the liver tissue and therefore does not predict behavior and prognosis especially in patients treated with partial resection (72). In contrast, the other staging systems take into

\section{\begin{tabular}{l|l} 
TABLE 1 & The pTNM classification and staging (2017)
\end{tabular}}

\section{Tumor}

\begin{tabular}{ll}
\hline T0 & No tumor \\
T1 & Solitary tumor smaller or larger than $2 \mathrm{~cm}$ without vascular invasion \\
Tla & Solitary tumor smaller or equal to $2 \mathrm{~cm}$ \\
Tlb & Solitary tumor larger than $2 \mathrm{~cm}$ without vascular invasion \\
T2 & $\begin{array}{l}\text { Solitary tumor larger than } 2 \mathrm{~cm} \text { with vascular invasion; or multiple tumors, none } \\
\text { larger than } 5 \mathrm{~cm}\end{array}$ \\
T3 & Multiple tumors, at least one of which is larger than $5 \mathrm{~cm}$ \\
T4 & Single tumor or multiple tumors of any size involving a major branch of the portal \\
& $\quad$ vein or hepatic vein; Tumor(s) with direct invasion of adjacent organs other than \\
the gallbladder; Perforation of visceral peritoneum
\end{tabular}




\section{TABLE 2 The Okuda and the CLIP staging systems}

\begin{tabular}{|c|c|c|}
\hline \multicolumn{3}{|c|}{ Okuda } \\
\hline Parameters & Criteria & Points $^{\mathrm{a}}$ \\
\hline Tumor size by imaging & $>50 \%$ & 1 \\
\hline Cross-sectional area & $<50 \%$ & 0 \\
\hline \multirow[t]{2}{*}{ Ascites } & Present & 1 \\
\hline & Absent & 0 \\
\hline \multirow[t]{2}{*}{ Serum Albumin (mg/dl) } & $>3$ & 0 \\
\hline & $<3$ & 1 \\
\hline \multirow[t]{3}{*}{ Serum total bilirubin (mg/dl) } & $<3$ & 0 \\
\hline & $>3$ & 1 \\
\hline & CLIP & \\
\hline \multirow[t]{3}{*}{ Child-Pugh class } & A & 0 \\
\hline & B & 1 \\
\hline & C & 2 \\
\hline \multirow[t]{3}{*}{ Tumor morphology } & Single nodule $<50 \%$ area & 0 \\
\hline & Multiple nodules $<50 \%$ area & 1 \\
\hline & Massive $>50 \%$ area & 2 \\
\hline \multirow[t]{2}{*}{ AFP (ng/mL) } & $<400$ & 0 \\
\hline & $\geq 400$ & 1 \\
\hline \multirow[t]{2}{*}{ Portal vein thrombosis } & No & 0 \\
\hline & Yes & 1 \\
\hline
\end{tabular}

${ }^{\mathrm{a}}$ Total points $=$ Stage

consideration of the background liver function, predicting prognosis considerably better, but are not suitable for orientating therapy. The Okuda staging system is efficient in identifying patients who have very poor prognosis (Stage III) but fails to distinguish different prognosis in patients grouped as Stage I and II $(73,74)$. The CLIP staging system predicts survival more accurately in those heterogenous group staged as I and II in the Okuda staging system but also fails in orienting adequate therapy (75). Finally, the BCLC staging system identifies early HCC for aggressive therapy but fails again to orientate adequate therapy in the more advanced stages. As illustrated in Tables 2 and 3, both CLIP and the BLCC staging systems use Child-Pugh class when staging HCC. This scoring system is based on laboratory tests such as serum albumin, serum bilirubin and prothrombin time as well as the presence or absence of ascites and hepatic encephalopathy $(76,77)$. 


\section{TABLE 3 The BCLC staging system}

\begin{tabular}{|c|c|c|c|c|}
\hline Stage & & $\begin{array}{l}\text { Performance } \\
\text { Status }\end{array}$ & Tumor Stage & Liver Function \\
\hline \multirow[t]{4}{*}{$A=$ Early } & $\mathrm{Al}$ & 0 & Single, $<5 \mathrm{~cm}$ & $\begin{array}{l}\text { No portal HTN and normal } \\
\text { bilirubin }\end{array}$ \\
\hline & A2 & 0 & Single, $<5 \mathrm{~cm}$ & Portal HTN and normal bilirubin \\
\hline & A3 & 0 & Single, $<5 \mathrm{~cm}$ & Portal HTN and elevated bilirubin \\
\hline & A4 & 0 & 3 tumors $<3 \mathrm{~cm}$ & Child-Pugh class A-B \\
\hline $\mathrm{B}=$ Intermediate & & 0 & Large multinodular & Child-Pugh class A-B \\
\hline$C=$ Advanced & & 1 and 2 & $\begin{array}{l}\text { vascular invasion } \\
\text { extrahepatic } \\
\text { spread }\end{array}$ & Child-Pugh class A-B \\
\hline $\mathrm{D}=$ End-stage & & 3 and 4 & Any & Child-Pugh class C \\
\hline
\end{tabular}

\section{TREATMENT}

The therapeutic options for HCC consist of liver transplantation, hepatic resection, ablation, chemoembolization and chemotherapy. The best available treatment is transplantation removing the entire tumor and replacing the diseased liver (usually cirrhotic) by a new functional healthy organ. However, due to limitations regarding availability of donor organs other alternatives should be considered. Living donor transplantation is an alternative option that has been reported to have similar results in terms of survival rate (78). Contraindications for liver transplant include extrahepatic spread, multiple tumors with one of the lesions larger than $3 \mathrm{~cm}$ and a single tumor larger than $5 \mathrm{~cm}$ emphasizing the need for proper staging (79-82). Up to $75 \%$ of the patients that received a transplant, previously had received transarterial chemoembolization (TACE) and one third of this same population had previous radiofrequency ablation (RFA) preventing progression of disease and winning time until a donor is available (83). If no evidence of medical liver disease and/or cirrhosis is documented, the patient may be offered partial hepatectomy as curative therapy (84). The three-year disease-free survival in cirrhotic patients treated with partial hepatectomy is $18 \%$, whereas it is $83 \%$ in patients treated by transplantation (85).

\section{CONCLUSION}

HCC is a frequent tumor endemic in areas of frequent infectious hepatitis. Patients with confirmed diagnosis of infectious hepatitis should be screened for early hepatocellular carcinoma and possible therapy. Early detection involves 
serologic markers, mostly AFP and radiologic studies. Staging systems attempt to subdivide the cases of hepatocellular carcinoma in subgroups to predict behavior and prognosis as well as orientate therapy. Curative therapy may be achieved with either resection and/or transplant. Adjuvant therapy such and TACE and RFA are offered as palliative care in attempt to win some time until a donor liver is available.

Conflict of interest: The author declares no potential conflict of interest with respect to research, authorship and/or publication of this chapter.

Copyright and permission statement: The author confirms that the materials included in this chapter do not violate copyright laws. Where relevant, appropriate permissions have been obtained from the original copyright holder(s), and all original sources have been appropriately acknowledged or referenced.

\section{REFERENCES}

1. KatyalS, Oliver IIIJH, Peterson MS, FerrisJV, Carr BS, Baron RL. Extrahepatic Metastases of Hepatocellular Carcinoma. Radiol. 2000; Sep 216(3). https://doi.org/10.1148/radiology.216.3.r00se24698

2. Bray F, Ferlay J, Soerjomataram I, Siegel RL, Torre LA, Jemal A. Global cancer statistics 2018: GLOBOCAN estimates of incidence and mortality worldwide for 36 cancers in 185 countries. CA Cancer J Clin. 2018;68(6):394-424. https://doi.org/10.3322/caac.21492

3. El-Serag HB, Kanwal F. Epidemiology of hepatocellular carcinoma in the United States: where are we? Where do we go? Hepatology. 2014;60(5):1767-75. https://doi.org/10.1002/hep.27222

4. Patti AM, Santi AL, Pompa MG, Giustini C, Vescia N, Mastroeni I, et al. Viral hepatitis and drugs: a continuing problem. Int J Epidemiol. 1993;22(1):135-9. https://doi.org/10.1093/ije/22.1.135

5. Bertuccio P, Turati F, Carioli G, Rodriguez T, La Vecchia C, Malvezzi M, et al. Global trends and predictions in hepatocellular carcinoma mortality. J Hepatol. 2017;67(2):302-9. https://doi. org/10.1016/j.jhep.2017.03.011

6. Tang A, Hallouch O, Chernyak V, Kamaya A, Sirlin CB. Epidemiology of hepatocellular carcinoma: target population for surveillance and diagnosis. Abdom Radiol. 2018;43:13-25. https://doi. org/10.1007/s00261-017-1209-1

7. Parkin DM, Bray F, Ferlay J, Pisani P. Estimating the world cancer burden: Globocan 2000; Int J Cancer. 2001;94:153-6. https://doi.org/10.1002/ijc.1440

8. Zhang W, Shi J, Li R, Han Z, Li L, Li G, et al. Effectiveness of Olaparib Treatment in a Patient with Gallbladder Cancer with an ATM -Inactivating Mutation. Oncologist. 2020;25:375-9. https://doi. org/10.1634/theoncologist.2019-0498

9. Brar TS, Hilgenfeldt E, Soldevila-Pico C. Etiology and Pathogenesis of Hepatocellular Carcinoma. In: Liu C, editor. Precision Molecular Pathology of Liver Cancer. Molecular Pathology Library. Springer, Cham; 2018.p 1-15. https://doi.org/10.1007/978-3-319-68082-8_1

10. Poon D, Anderson BO, Chen LT, Tanaka K, Lau WY, Cutsem EV et al. Management of hepatocellular carcinoma in Asia: consensus statement from the Asian Oncology Summit 2009. Lancet Oncol. 2009;10(11):1111-8. https://doi.org/10.1016/S1470-2045(09)70241-4

11. Shen T, Liu Y, Shang J, Xie Q, Li J, Yan M et al. Incidence and Etiology of Drug-Induced Liver Injury in Mainland China. Gastroenterology. 2019;156(8):2230-41.

12. Chen C, Yang H, Su J, Jen CL, You SL, Lu SN, et al. Risk of Hepatocellular Carcinoma Across a Biological Gradient of Serum Hepatitis B Virus DNA Level. JAMA. 2006;295(1):65-73. https://doi. org/10.1001/jama.295.1.65

13. Chen CJ, Yang HI, Iloeje UH. Hepatitis B virus DNA levels and outcomes in chronic hepatitis B. Hepatology. 2009;49:S72-S84. https://doi.org/10.1002/hep.22884 
14. Gomaa AI, Khan SA, Toledano MB, Waked I, Taylor-Robinson SD. Hepatocellular carcinoma: epidemiology, risk factors and pathogenesis. World J Gastroenterol. 2008;14(27):4300-8. https://doi. org/10.3748/wjg. 14.4300

15. Montalto G, Cervello M, Giannitrapani L, Dantona F, Teraanova A, Castagnetta LAM. Epidemiology, Risk Factors, and Natural History of Hepatocellular Carcinoma. Ann NY Acad Sci. 2002;963:13-20. https://doi.org/10.1111/j.1749-6632.2002.tb04090.x

16. Alberts SR, Lanier AP, McMahon BJ. Clustering of hepatocellular carcinoma in Alaska native families. Genet Epidemiol. 1991;8:127-39. https://doi.org/10.1002/gepi.1370080206

17. Shen FM, Lee MK, Gong HM. Complex segregation analysis of primary hepatocellular carcinoma in Chinese families: interaction of inherited susceptibility and hepatitis B viral infection. Am J Hum Genet. 1991;49:88. 18. Leong TY, Leong AS. Epidemiology and carcinogenesis of hepatocellular carcinoma. HPB (Oxford) 2005;7(1):5-15. https://doi.org/10.1080/13651820410024021

19. Blum HE, Offensperger WB, Walter E, Offensperger S, Wahl A, Zeschnigk C, et al. Hepatocellular carcinoma and hepatitis B virus infection: molecular evidence for monoclonal origin and expansion of malignantly transformed hepatocytes. J Cancer Res Clin Oncol. 1987;113:466-72. https://doi. org/10.1007/BF00390041

20. Machida K, Cheng KT, Sung VM, Shimodaira S, Lindsay KL, Levine AM, et al. Hepatitis C virus induces a mutator phenotype: enhanced mutations of immunoglobulin and protooncogenes. Proc Natl Acad Sci. U S A 2004;101(12):4262-7. https://doi.org/10.1073/pnas.0303971101

21. Nault J, Mallet M, Pilati C, Calderaro J, Bioulac-Sage P, Laurent C, et al. High frequency of telomerase reverse-transcriptase promoter somatic mutations in hepatocellular carcinoma and preneoplastic lesions. Nat Commun. 2013;4:2218. https://doi.org/10.1038/ncomms3218

22. Hussain S, Schwank J, Staib F, Wang XW, Harris CC. TP53 mutations and hepatocellular carcinoma: insights into the etiology and pathogenesis of liver cancer. Oncogene. 2007;26(15):2166-76. https:// doi.org/10.1038/sj.onc. 1210279

23. Villanueva A, Llovet JM. Liver cancer in 2013: Mutational landscape of HCC-the end of the beginning. Nat Rev Clin Oncol. 2014;11(2):73-4. https://doi.org/10.1038/nrclinonc.2013.243

24. Dhanasekaran R, Bandoh S, Roberts LR. Molecular pathogenesis of hepatocellular carcinoma and impact of therapeutic advances. F1000Research 2016, 5(F1000 Faculty Rev):879. https://doi. org/10.12688/f1000research.6946.1

25. Giannini A, Zampi G, Bartoloni F, Omer S. Morphological precursors of hepatocellular carcinoma: a morphometrical analysis. Hepatogastroenterology. 1987;34(3):95-7.

26. Chou CT, Chou JM, Chang TA, Huang SF, Chen CB, Chen YL et al. Differentiation between dysplastic nodule and early-stage hepatocellular carcinoma: the utility of conventional MR imaging. World J Gastroenterol. 2013;19(42):7433-9. https://doi.org/10.3748/wjg.v19.i42.7433

27. Roncalli M. Hepatocellular nodules in cirrhosis: Focus on diagnostic criteria on liver biopsy. A Western experience. Liver Transpl. 2004;10:S9-S15. https://doi.org/10.1002/lt.20047

28. Barthelmes L,Tait IS. Liver cell adenoma and liver cell adenomatosis. HPB. 2005;7:186-96. https:// doi.org/10.1080/13651820510028954

29. Carrasco D, Barrachina M, Prieto M, Berenguer J. Clomiphene citrate and liver-cell adenoma. N Engl J Med. 1984;310(7):1120-1. https://doi.org/10.1056/NEJM198404263101716

30. Coombes GB, Reiser J, Paradinas FJ, Burn I. An androgen-associated hepatic adenoma in a transsexual. Brit J Surg. 1978;65(2):869-70. https://doi.org/10.1002/bjs.1800651212

31. Fermand JP, Levy Y, Bouscary D, D'Agay MF, Clot P, Frija J, Brouet JC. Danazol-induced hepatocellular adenoma. Am J Med. 1990;88(5):529-30. https://doi.org/10.1016/0002-9343(90)90434-F

32. Bellamy COC, Maxwell RS, Prost S, Azodo IA, Powell JJ, Manning JR. The value of immunophenotyping hepatocellular adenomas: consecutive resections at one UK centre. Histopathology. 2013;62:431-45. https://doi.org/10.1111/his.12011

33. Bioulac-Sage P, Laumonier H, Couchy G, Le Bail B, Sa Cunha A, Rullier A et al. Hepatocellular adenoma management and phenotypic classification: the Bordeaux experience. Hepatology. 2009;50:481-9. https://doi.org/10.1002/hep.22995

34. Honda T, Miyaaki H, Ichikawa T, Taura N, Miuma S, Shibata H et al. Clinical characteristics of hepatocellular carcinoma in elderly patients. Onco Lett. 2011;2(5):851-4. https://doi.org/10.3892/ ol.2011.359 
35. Juturi JV, Hopkins T, Farhangi M. Severe leukocytosis with neutrophilia (leukemoid reaction) in alcoholic steatohepatitis. Am J Gastroenterol. 1998;93(6):1013. https://doi.org/10.1111/j. 1572-0241.1998.1013a.x

36. Kew MC, Fisher JW. Serum erythropoietin concentrations in patients with hepatocellular carcinoma. Cancer. 1986;58(11):2485-88. https://doi.org/10.1002/1097-0142(19861201)58:11 $<2485:: A I D-C N C R 2820581122>3.0 . C O ; 2-\mathrm{N}$

37. Yen TC, Wang CC, Lee SD, Yen SH. Hypercalcemia and parathyroid hormone-related protein in hepatocellular carcinoma. Liver. 1993;13(6):311. https://doi.org/10.1111/j.1600-0676.1993. tb00651.x

38. Solinas A, Biscarini L, Morrelli A, Favero AD. Hepatocellular Carcinoma and the Watery Diarrhea Syndrome. Arch Surg. 1988;123(1):124. https://doi.org/10.1001/archsurg. 1988.01400250134033

39. Gregory B, Ho VC. Cutaneous manifestations of gastrointestinal disorders. Part II. J Am Acad Dermatol. 1992;26(3 Pt 2):371-383. https://doi.org/10.1016/0190-9622(92)70059-O

40. Jiang X, Ke C, Zhang G, Zhang X, Sai K, Chen Z. Brain metastases from hepatocellular carcinoma: clinical features and prognostic factors. BMC Cancer. 2012;12:49. https://doi.org/ 10.1186/1471-2407-12-49

41. Harding JJ, Abu-Zeinah G, Chou JF, Owen DH, Ly M, Lowery MA et al. Frequency, Morbidity, and Mortality of Bone Metastases in Advanced Hepatocellular Carcinoma. J Natl Compr Canc Netw. 2018;16(1):50-8. https://doi.org/10.6004/jnccn.2017.7024

42. Zhao YJ et al. Tumor markers for hepatocellular carcinoma. Mol Clin Oncol. 2013;1(4):593-8. https:// doi.org/10.3892/mco.2013.119

43. Zhou L, Liu J, Luo F. Serum tumor markers for detection of hepatocellular carcinoma. World J Gastroenterol. 2006;12(8):1175-81. https://doi.org/10.3748/wjg.vl2.i8.1175

44. Tan CK, Law NM, Ng HS, Machin D. Simple clinical prognostic model for hepatocellular carcinoma in developing countries and its validation. J Clin Oncol. 2003;21:2294-8. https://doi.org/10.1200/ JCO.2003.03.151

45. Khien VV, Mao HV, Chinh TT, Ha PT, Bang MH, Lac BV et al. Clinical evaluation of lentil lectinreactive alpha-fetoprotein-L3 in histology-proven hepatocellular carcinoma. Int J Biol Markers. 2001;16:105-111. https://doi.org/10.1177/172460080101600204

46. Oka H, Saito A, Ito K, Kumada T, Satomura S, Kasugai H et al. Multicenter prospective analysis of newly diagnosed hepatocellular carcinoma with respect to the percentage of Lens culinaris agglutinin-reactive alpha-fetoprotein. J Gastroenterol Hepatol. 2001;16:1378-83. https://doi. org/10.1046/j.1440-1746.2001.02643.x

47. Capurro M, Wanless IR, Sherman M, Deboer G, Shi W, Miyoshi E et al. Glypican-3: a novel serum and histochemical marker for hepatocellular carcinoma. Gastroenterology. 2003;125:89-97. https://doi. org/10.1016/S0016-5085(03)00689-9

48. Nakatsura T, Yoshitake Y, Senju S, Monji M, Komori H, Motomura Y et al. Glypican-3, overexpressed specifically in human hepatocellular carcinoma, is a novel tumor marker. Biochem Biophys Res Commun. 2003;306:16-25. https://doi.org/10.1016/S0006-291X(03)00908-2

49. Minata M, Nishida N, Komeda T, Azechi H, Katsuma H, Nishimura T et al. Postoperative detection of alpha-fetoprotein mRNA in blood as a predictor for metastatic recurrence of hepatocellular carcinoma. J Gastroenterol Hepatol. 2001;16:445-51. https://doi.org/10.1046/j.1440-1746.2001.02461.x

50. Ijichi M, Takayama T, Matsumura M, Shiratori Y, Omata M, Makuuchi M. alpha-Fetoprotein mRNA in the circulation as a predictor of postsurgical recurrence of hepatocellular carcinoma: a prospective study. Hepatology. 2002;35:853-60. https://doi.org/10.1053/jhep.2002.32100

51. El-Tayeh SF, Hussein TD, El-Houseini ME, Amer MA, El-Sherbini M, Elshemey WM. Serological biomarkers of hepatocellular carcinoma in Egyptian patients. Dis Markers. 2012;32(4):255-63. https:// doi.org/10.1155/2012/962320

52. Bargellini I, Battaglia V, Bozzi E, Lauretti DL, Lorenzoni G, Bartolozzi C. Radiological diagnosis of hepatocellular carcinoma. J Hepatocell Carcinoma. 2014;1:137-48. https://doi.org/10.2147/JHC. S44379

53. Singal A, Volk ML, Waljee A, Salgia R, Higgins P, Rogers MA et al. Meta-analysis: surveillance with ultrasound for early-stage hepatocellular carcinoma in patients with cirrhosis. Aliment Pharmacol Ther. 2009;30:37-47. https://doi.org/10.1111/j.1365-2036.2009.04014.x 
54. Waghray A, Murali AR, Menon KN. Hepatocellular carcinoma: From diagnosis to treatment. World J Hepatol. 2015;7(8):1020-9. https://doi.org/10.4254/wjh.v7.i8.1020

55. Himeno H, Enzan H, Saibara T, Onishi S, Yamamoto Y. Hitherto unrecognized arterioles within hepatocellular carcinoma. J Pathol. 1994;174:217-22. https://doi.org/10.1002/path.1711740311

56. Kin M, Torimura T, Ueno T, Inuzuka S, Tanikawa K. Sinusoidal capillarization in small hepatocellular carcinoma. Pathol Int 1994:44:771-8. https://doi.org/10.1111/j.1440-1827.1994.tb02925.x

57. Forner A, Vilana R, Ayuso C, Bianchi L, Solé M, Ayuso JR et al. Diagnosis of hepatic nodules $20 \mathrm{~mm}$ or smaller in cirrhosis: prospective validation of the noninvasive diagnostic criteria for hepatocellular carcinoma. Hepatology. 2008;47:97-104. https://doi.org/10.1002/hep.21966

58. Leoni S, Piscaglia F, Golfieri R, Camaggi V, Vidili G, Pini P et al. The impact of vascular and nonvascular findings on the noninvasive diagnosis of small hepatocellular carcinoma based on the EASL and AASLD criteria. Am J Gastroenterol. 2010;105(3):599-609. https://doi.org/10.1038/ ajg.2009.654

59. International Consensus Group for Hepatocellular Neoplasia Pathologic diagnosis of early hepatocellular carcinoma: a report of the International Consensus Group for Hepatocellular Neoplasia. Hepatology. 2009;49:658-64. https://doi.org/10.1002/hep.22709

60. Bargellini I, Battaglia V, Bozzi E, Lauretti DL, Lorenzoni G, Bartolozzi C. Radiological diagnosis of hepatocellular carcinoma. J Hepatocell Carcinoma. 2014;1:137-148. https://doi.org/10.2147/JHC.S44379

61. Cochand-Priollet B, Chagnon S, Ferrand J, Blery M, Hoang C, Galian A. Comparison of cytologic examination of smears and histologic examination of tissue cores obtained by fine needle aspiration biopsy of the liver. Acta Cytol. 1987;31(4):476-80.

62. Silva MA, Hegab B, Hyde C, Guo B, Buckels JA, Mirza DF. Needle track seeding following biopsy of liver lesions in the diagnosis of hepatocellular cancer: a systematic review and meta-analysis. Gut. 2008;57:1592-6. https://doi.org/10.1136/gut.2008.149062

63. Brunt EM. Histopathologic features of hepatocellular carcinoma. Clin Liver Dis. 2012;1:194-9. https://doi.org/10.1002/cld.98

64. Jain D. Tissue diagnosis of hepatocellular carcinoma. J Clin Exp Hepatol. 2014;4(Suppl 3):S67-S73. https://doi.org/10.1016/j.jceh.2014.03.047

65. Timek DT, Shi J, Liu H, Lin F. Arginase-1, HepPar-1, and Glypican-3 are the most effective panel of markers in distinguishing hepatocellular carcinoma from metastatic tumor on fineneedle aspiration specimens. Am J Clin Pathol. 2012;138(2):203-210. https://doi.org/10.1309/ AJCPKIZC9WNHCCMU

66. Ishak KG, Goodman ZD, Stocker JT. Tumors of the Liver and Intrahepatic Bile Ducts. In; Rosai J, editor. Atlas of Tumor Pathology. Armed Forces Institute of Pathology Washington, DC. 2001 3rd Series. Fascicle 31 .

67. Hirohashi S, Ishak KG, Kojiro M. Hepatocellular carcinoma. In: Hamilton S.R., Aaltonen L.A., editors. Tumors of the Digestive System. World Health Organization Classification of Tumors.IARC Press; Lyon. 2000. pp. 159-172.

68. Jakate S, Yabes A, Giusto D. Diffuse cirrhosis-like hepatocellular carcinoma: a clinically and radiographically undetected variant mimicking cirrhosis. Am J Surg Pathol. 2010;34:935-41. https://doi. org/10.1097/PAS.0b013e3181ddf52f

69. Goodman ZD, Terraciano LM. Tumours and tumour-like lesions of the liver. In: Burt AD, Portmann BC, Ferrell LD, editors. MacSween's Pathology of the Liver. 5th ed. Churchill Livingstone; Philadelphia, PA 2007. pp. 761-814.

70. Shiina S. Image-guided percutaneous ablation therapies for hepatocellular carcinoma. J Gastroenterol. 2009;44(suppl 19):122-31. https://doi.org/10.1007/s00535-008-2263-9

71. Befeler AS, Di Bisceglie AM. Hepatocellular carcinoma: diagnosis and treatment. Gastroenterology. 2002;122(6):1609-19. https://doi.org/10.1053/gast.2002.33411

72. Izumi R, Shimizu K, Ii T, Yagi M, Matsui O, Nonomura A et al. Prognostic factors of hepatocellular carcinoma in patients undergoing hepatic resection. Gastroenterology. 1994;106:720-7. https://doi. org/10.1016/0016-5085(94)90707-2

73. Calvet X, Bruix J, Brú C, Gines P, Vilana R, Sole M. Natural history of hepatocellular carcinoma in Spain. Five year's experience in 249 cases. J Hepatol. 1990;10(3):311-7. https://doi. org/10.1016/0168-8278(90)90138-H 
74. Farinati F, Rinaldi M, Gianni S, Naccarato R. How should patients with hepatocellular carcinoma be staged? Validation of a new prognostic system. Cancer. 2000;89(11):2266-73. https://doi. org/10.1002/1097-0142(20001201)89:11<2266::AID-CNCR15>3.0.CO;2-0

75. Llovet JM, Bruix J. Prospective validation of the Cancer of the Liver Italian Program (CLIP) score: a new prognostic system for patients with cirrhosis and hepatocellular carcinoma. Hepatology. 2000;32(3):679-80. https://doi.org/10.1053/jhep.2000.16475

76. Current Surgical Therapy: Expert Consult - Online and Print, 1le (Current Therapy). Saunders 2019.

77. Oh's Intensive Care Manual: Expert Consult: Online and Print, 7e. Butterworth-Heinemann. 2013

78. Schiano TD, Kim-Schluger L, Gondolesi G, Miller CM. Adult living donor liver transplantation: The hepatologist's perspective. Hepatology. 2001;33:3-9. https://doi.org/10.1053/jhep.2001.21489

79. Iwatsuki S, Starzl TE. Role of liver transplantation in the treatment of hepatocellular carcinoma. Semin Surg Oncol. 1993;9:337-40. https://doi.org/10.1002/ssu.2980090411

80. Bismuth H, Chiche L, Adam R, Castaing D, Diamond T, Dennison A. Liver resection versus transplantation for hepatocellular carcinoma in cirrhotic patients. Ann Surg. 1993;218:145-51. https://doi. org/10.1097/00000658-199308000-00005

81. Pichlmayr R, Weimann A, Steinhoff G, Ringe B. Liver transplantation for hepatocellular carcinoma: clinical results and future aspects. Cancer Chemother Pharmacol. 1992;31:S157-S161. https://doi. org/10.1007/BF00687127

82. Ismail T, Angrisani L, Gunson BK, Hubscher SG, Buckels JA,Neuberger JM et al. Primary hepatic malignancy:the role of liver transplantation. Br J Surg. 1990;77:983-87. https://doi.org/10.1002/ bjs. 1800770908

83. Rahimi RS, Trotter JF. Liver transplantation for hepatocellular carcinoma: outcomes and treatment options for recurrence. Ann Gastroenterol. 2015;28:323-30.

84. Loss GE, Nair S, Blazek JL, Farr GH, Eason JD. Liver Transplantation for Hepatocellular Carcinoma: The Ochsner Experience. Ochsner J. 2002;4(4):215-20.

85. Bismuth H, Chiche L, Adam R. Liver resection versus transplantation for hepatocellular carcinoma in cirrhotic patients. Ann Surg. 1993;218:145-51. https://doi.org/10.1097/00000658-199308000-00005 